\title{
The Impact of Foreign Direct Investment, Human Capital on Labour Productivity in Vietnam
}

\author{
Nguyen Tan Vinh ${ }^{1}$ \\ ${ }^{1}$ Academy of politics region, Ho Chi Minh, Vietnam \\ Correspondence: Nguyen Tan Vinh, Academy of politics region II, 99 Man Thiep st, Hiep Phu, Q9, Ho Chi \\ Minh. Tel: 84-972-188-451. E-mail: vinhnt@hcma2.edu.vn
}

Received: March 3, 2019

Accepted: March 31, 2019

Online Published: April 15, 2019

doi:10.5539/ijef.v11n5p97

URL: https://doi.org/10.5539/ijef.v11n5p97

\begin{abstract}
Vietnam is a country which has an attractive level of attracting foreign direct investment (Hereafter FDI) in the region with many preferential policies for investors. FDI attraction aims to help economic growth as well as increase the country's labour productivity. Therefore, the author conducted research to the impact of FDI and human capital on labor productivity of Vietnam. With data analysis techniques using ARDL model with data collected from 1990 to 2017, research result shows that FDI has a positive impact on labor productivity in short term and long term. The factor of university qualification (human capital) only has a positive impact on labor productivity in the long term.
\end{abstract}

Keywords: foreign direct investment, human capital, labour productivity

\section{Introduction}

\subsection{Introduce the Problem}

Improving and promoting labor productivity is one of the core issues for Vietnam's economy today. Increasing labor productivity is the decisive factor for the competitiveness of businesses and the economy. High labor productivity is synonymous with rapid and sustainable development, preventing lagging behind other countries in the region. Labor productivity for the whole economy at current prices in 2017 is estimated at VND 93.2 million/employee (equivalent to $\$ 4,166 /$ employee). Calculated at the comparative price in 2010 , the total labor productivity in 2017 increased by 6\% compared to 2016, the average period of 2011-2017 increased by 4.7\%/year (Lam, 2018). For the 10-year period of 2007-2016, labor productivity by purchasing power equivalent to 2011 (PPP 2011) of Vietnam increased by an annual average of $4.2 \%$ / year. However, the current level of labor productivity in Vietnam is still very low compared to other countries in the region. According to PPP 2011, Vietnam's labor productivity in 2016 reached $\$ 9,894$, only $7.0 \%$ of Singapore's productivity level; $17.6 \%$ of Malaysia; $36.5 \%$ of Thailand; $42.3 \%$ of Indonesia and $56.7 \%$ of Philippine's labor productivity. This shows that the gap and challenges of the Vietnamese economy face in keeping up with the productivity levels of the countries (GSO, 2018). Therefore, the improvement of labor productivity is always concerned by Vietnamese strategists in order to promote economic development in the integration period.

Foreign direct investment plays an important role in creating capital accumulation, job creation as well as commercial opportunities for developing countries (Gui-Diby, 2016; Li \& Tanna, 2018). At the same time foreign direct investment also helps bring modern investment technology to host countries and labor productivity related to this investment category (Alvarado, Iñiguez, \& Ponce, 2017; Li \& Tanna, 2018). The impact of foreign direct investment on labor productivity through cross-sectoral linkages (across sectors / ministries - vertically) instead of horizontal (intra-industry) links (Javorcik, 2004; Liu, 2004). For developing countries, the investment of foreign enterprises will bring international business with higher professionalism than the average domestic activities. It is the professional management that will help improve productivity ( $\mathrm{Li} \&$ Tanna, 2018). The movement of labor structure in the direction of increasing the proportion of labor in the FDI sector has contributed about $29.3 \%$ to the overall labor productivity growth of the economy in the period of $2006-2016$ (Investment Department, 2018).

Human resource shows internal forces in production activities of individuals as well as businesses. The impact of human resource are assessed as positive on labor productivity (Chang, Wang, \& Liu, 2016). In the enterprise, 
determining competitiveness is based on many indicators such as labor productivity, cost advantage, product quality or export / import ratio (Francis \& Tharakan, 1989; Niosi , 1991). With high skills or highly educated people, workers can create more value than lower skilled people under the same working conditions (Cörvers, 1996). Higher educated people are more likely to adapt to technological change faster and it is these people who tend to create better innovation (Nelson \& Phelps, 1966; Phelps, 1980)

Studies in the world have shown the relationship between foreign direct investment, human resources to labor productivity. However, in the Vietnamese economic environment, such studies are limited. No official research has been done to help find this rule in Vietnam. Therefore, the author studies the impact of foreign direct investment and human capital on labor productivity in Vietnam.

\subsection{Literature Review}

Labor productivity is defined as the level of income generated per capita (Li \& Tanna, 2018). The higher the income per capita, the higher the productivity due to internal factors (as individuals have an increase in work experience, skills or education, leading to increased income levels). or external factors (economic growth, better job opportunities, inflation).

Foreign direct investment (FDI) means the transfer of capital, technology or any asset from abroad to invest in an investment recipient country to establish or control an enterprise for profit-making business purposes (Duy, Kien, \& Tuyen, 2014). FDI will help solve the problem of employment as well as promote economic development of host countries, especially developing countries (Duy, Kien, \& Tuyen, 2014); addressing the shortage of investment capital, making economic restructuring (Wang và Bloomstrom, 1992), providing new technology or transferring management experiences to local businesses (Chawa et al., 2012). With the creation of more modern production technology and the first working processes will help improve the labor productivity of the country receiving FDI.

The human resource in this study are considered based on the proportion of university students in Vietnam. University qualification in Vietnamese education is considered the highest level of education before individuals want to go out to work after graduating from university. Favorable jobs or high value for the country are primarily for college graduates (lower levels of education but still able to create good jobs but at a competitive level This is a source of economic development as well as higher productivity in the long term (Chang et al., 2016; Nelson \& Phelps, 1966). Quality resources will increase marginal value compared to low or medium human resources. With quality resources, it brings competitiveness to create production value as well as increase creativity at work.

\section{Method}

\subsection{Research Model}

To assess the impact of FDI on labor productivity, the author referred to the research model of Boghean \& State (2015) and Li \& Tanna (2018). At the same time, assessing the impact of human resources on labor productivity will be referred to the Cobb-Douglas model and the model of Cörvers (1996); Chang et al (2015). At the same time, research done for Vietnam, the ARDL time series model will be used by the author. The research model is presented as follows:

$$
\begin{gathered}
\Delta L P_{\mathrm{t}}=\propto+\beta_{1} \Delta F D I_{\mathrm{t}-\mathrm{i}}+\beta_{2} \Delta U N I V E R S I T Y_{-} E D U T_{\mathrm{t}-\mathrm{i}}+\beta_{\mathrm{a}} \Delta L P_{\mathrm{t}-\mathrm{i}}+\beta_{4} F D I_{\mathrm{t}-1} \\
+\beta_{5} \text { UNIVERSITY }_{-} E D U T_{\mathrm{t}-1}+\varepsilon_{\mathrm{t}}
\end{gathered}
$$

\section{In which:}

$\Delta$ : Difference at $1^{\text {st; }}$;

LP: Labour productivity;

FDI: Foreign direct investment;

UNIVERSITY_EDU :Human capitap;

$\alpha$ : constant;

$\beta$ : Unknown parameters of the model.

$\varepsilon$ : white noise

The Hypothesis:

In this paper, the author hypothesizes as follows:

H1: Direct investment has a positive impact on labor productivity. 
H2: Human resource (university qualification rate) positively affects labor productivity.

With ARDL model, the steps to implement the model presented by the author follow these steps:

\section{Stationarity tests}

Time series of data, before analyzing, need to check the stationary to avoid the occurrence of spurious regressions that result in bias (Gujarati, 2003; Ramanathan, 2002; Thanh, N.T, Linh, D.T, \& Duy, N.V, 2016). In this research we also use unit tests to check whether the data series are stationary. Specifically, we use the augmented Dickey-Fuller test by the ADF method. ADF testing methods are described as follows:

$$
\Delta Y_{t}=\alpha_{o}+\beta Y_{t-1}+\sum_{j=1}^{k} \varphi_{j} \Delta Y_{t-j}+\varepsilon_{t}
$$

In which:

$\mathrm{Y}_{\mathrm{t}}$ : Time series;

$\mathrm{k}$ : The number of lags;

Et: white noise.

The ADF test results are quite sensitive to the selection of $\mathrm{k}$ lags, AIC is often chosen. These test hypotheses are:

$\mathrm{H} 0: \beta=0$ ( $\mathrm{Y}_{\mathrm{t}}$ series is not stationary);

$\mathrm{H} 1: \beta<0$ ( $\mathrm{Y}_{\mathrm{t}}$ series is stationary).

Determine the optimal lag

In economics, variables are often related not only in the present but also in the past (latency) so the time series needs to find the optimal latency (the optimal delay is the latency at which the variables are most interrelated). AIC is also used by the author to find the optimal delay.

\section{The long-term relationships}

Long-term relationships are tested based on Johansen testing with selected Trace statistics (Gujarati, 2003). The hypothesis of this test is stated as follows:

H0: No long-term relationship exists;

H1: Long-term relationship exists.

In the case of a long-term relationship, when estimating the ARDL model, there will be an additional long-term estimation based on the lag of the variables that have not been difference

Test the reliability of the model.

To ensure that the model is reliable, testing for autocorrelation, Heteroskedasticity test needs to be satisfied after running the model (Gujarati, 2003; Ramanathan, 2002).

\subsection{Data}

With analytical data by year the criteria in section 3.1, the author conducts data collection of Vietnam on Worldbank from 1990 to 2017 (the period after opening). After data collection is available, the author proceeds to encrypt the variable name and put it into Eviews 9 software for analysis (With time series data, EViews software is considered suitable for use)

\section{Results}

\subsection{Descriptive Statistics}

The table of statistical result shows that the average labor productivity of Vietnam is $\$ 871$ per capita for the period from 1990 to 2017. With FDI inflows to Vietnam averaging \$4.61 billion per year; Human resources through university education rate each year reached $13.76 \%$. Other detailed indicators are shown in table 1

Table 1. Descriptive statistics

\begin{tabular}{lccc}
\hline & LP & FDI & \multicolumn{2}{c}{$\begin{array}{c}\text { UNIVERSITY_EDU } \\
(\%)\end{array}$} \\
\hline Mean & (USD/year) & (USD) & 13.76252 \\
Maximum & 871.3023 & $4.61 \mathrm{E}+09$ & 30.43251 \\
Minimum & 2342.244 & $1.41 \mathrm{E}+10$ & 1.53179 \\
Observations & 94.8802 & $1.80 \mathrm{E}+08$ & 28 \\
\hline
\end{tabular}




\subsection{The Stationary Test}

The result of the stop test indicates that the variables are non-stationary (p-value of ADF test is greater than 0.05) but the first difference of the variables is stationary (p-value of the ADF test of the differential is less than 0.05)

Table 2 . The result of stationary test

\begin{tabular}{lll}
\hline & ADF-statistics & p-value \\
\hline FDI & -2.1925 & 0.2133 \\
University_Edu & 0.3153 & 0.9741 \\
LP & -1.0919 & 0.7034 \\
\hline ADF-statistics (Difference) & & \\
\hline FDI & -3.8622 & 0.0070 \\
University_Edu & -4.5321 & 0.0018 \\
LP & -5.4549 & 0.0001 \\
\hline
\end{tabular}

\subsection{The Optimal Lag}

The optimal latency test results show that the optimal lag selected according to AIC criteria is 1 . Therefore, in the ARDL model analysis, the author will use the lag 1 to analyze

Table 3. The optimal lag

\begin{tabular}{|c|c|c|c|c|c|c|}
\hline \multicolumn{7}{|c|}{ VAR Lag Order Selection Criteria } \\
\hline \multicolumn{7}{|c|}{ Endogenous variables: LLP LFDI UNIVERSITY_EDU } \\
\hline \multicolumn{7}{|c|}{ Exogenous variables: } \\
\hline \multicolumn{7}{|c|}{ Sample: 19902017} \\
\hline Lag & $\log \mathrm{L}$ & LR & FPE & AIC & SC & HQ \\
\hline 1 & -1.840946 & NA & $0.000598^{*}$ & $1.084095^{*}$ & $1.532174 *$ & $1.171564 *$ \\
\hline 2 & 3.300536 & 7.198075 & 0.000924 & 1.469946 & 2.366105 & 1.644886 \\
\hline 3 & 13.09759 & 10.77676 & 0.000993 & 1.390241 & 2.734480 & 1.652651 \\
\hline \multicolumn{7}{|c|}{ * indicates lag order selected by the criterion } \\
\hline \multicolumn{7}{|c|}{ LR: sequential modified LR test statistic (each test at 5\% level) } \\
\hline \multicolumn{7}{|c|}{ FPE: Final prediction error } \\
\hline \multicolumn{7}{|c|}{ AIC: Akaike information criterion } \\
\hline \multicolumn{7}{|c|}{ SC: Schwarz information criterion } \\
\hline HQ: Han & $\mathrm{nn}$ informati & tion & & & & \\
\hline
\end{tabular}

\section{The long-term relationships}

With p-value less than 0.05 , there can be two long-term relationships between research variables. Therefore, in regression analysis, the author will conduct short-term and long-term impact analysis in the ARDL model

Table 4. Long-term relationship test results

\begin{tabular}{lllll}
\hline \multicolumn{2}{l}{ Series: LLP LFDI UNIVERSITY_EDU } & & \\
\hline Hypothesis & & Trace statistics & Critical Value 5\% \\
H0 & H1 & & & 0.0000 \\
\hline LR Trace & & 108.5229 & 35.1928 & 0.0492 \\
\hline $\mathrm{r}=0$ & $\mathrm{r}>=1$ & 20.3103 & 20.2618 & 0.3347 \\
$\mathrm{r}=<1$ & $\mathrm{r}>=2$ & 4.5633 & 9.1645 & \\
$\mathrm{r}=<2$ & $\mathrm{r}>=3$ & & & \\
\hline
\end{tabular}

\subsection{Regression}

The ARDL model results in a lag of 1 after eliminating the multicollinear relationships so the final model obtained is ARDL $(1,1,1)$. The result shows two short-term and long-term relationships between variables on labor productivity. In the short and long term, FDI has a positive impact on labor productivity (p-value in the short and long term are less than 0.05). While, the factor of university education does not affect short-term labor 
productivity ( $\mathrm{p}$-value value in the short term is greater than 0.05 ). However, in the long term, higher education has a positive impact on labor productivity ( $\mathrm{p}$-value in the long term less than 0.05 ).

Table 5. The result of ARDL model

\begin{tabular}{|c|c|c|c|c|}
\hline \multicolumn{5}{|l|}{ Short Run Coefficients } \\
\hline Variable & Coefficient & Std. Error & t-Statistic & p-value \\
\hline $\mathrm{D}(\mathrm{LFDI})$ & 0.1677 & 0.0505 & 3.3190 & 0.0038 \\
\hline D(UNIVERSITY_EDU) & 0.0080 & 0.0117 & 0.6786 & 0.5060 \\
\hline CointEq(-1) & -0.3085 & 0.1359 & -2.2704 & 0.0357 \\
\hline \multicolumn{5}{|c|}{ Cointeq $=L L P-\left(0.3564 * L F D I+0.0516 * U N I V E R S I T Y \_E D U \quad-1.8475\right)$} \\
\hline \multicolumn{5}{|c|}{ Long Run Coefficients } \\
\hline Variable & Coefficient & Std. Error & $\mathrm{t}$-Statistic & p-value \\
\hline LFDI & 0.3564 & 0.1075 & 3.3157 & 0.0038 \\
\hline UNIVERSITY_EDU & 0.0516 & 0.0125 & 4.1298 & 0.0006 \\
\hline $\mathrm{C}$ & -1.8475 & 2.1567 & -0.8566 & 0.4029 \\
\hline
\end{tabular}

ARDL regression result shows the important role of FDI in promoting labor productivity growth in Vietnam in both short and long term. It can be seen that foreign enterprises investing more in Vietnam with advanced technologies will make Vietnam's GDP increase due to improved jobs. In addition, the university education factor has no impact on short-term labor productivity due to the lack of strong fluctuations in the quality of university education in the recent years. making a difference or a strong breakthrough in the past as well as the present. However, in the long term, higher education has a positive effect on labor productivity. With a high level of education and the integration of the international economy in the future will be a potential market to help promote the academic performance.

\section{Discussion}

With the data collection of research data and analysis of ARDL regression model, it shown the real impact of FDI on Vietnam's economy in general and labor productivity in particular. From that, it can be seen that attracting FDI investment is always necessary for developing countries like Vietnam. At the same time, the factor of human resource through university education also indicates positive effects in the long-term on labor productivity also indicates that the concentration of higher education does not clearly show a strong impact on productivity dynamic. However, in the future, investment in higher education is a strategy to increase labor productivity

\section{References}

Alvarado, R., Iñiguez, M., \& Ponce, P. (2017). Foreign direct investment and economic growth in Latin America. Economic Analysis and Policy, 56, 176-187. https://doi.org/10.1016/j.eap.2017.09.006

Chang, C. F., Wang, P., \& Liu, J. T. (2016). Knowledge spillovers, human capital and productivity. Journal of Macroeconomics, 47, 214-232. https://doi.org/10.1016/j.jmacro.2015.11.003

Duy, N. V., Kien, T. D., \& Tuyen, B. Q. (2014). Anh hương của đầu tu trưc tiếp nước ngoài đến tăng truởng kinh tế Việt Nam giai đoạn 1990-2013 bằng mô hình ARDL. Retrieved February 28, 2019, from http://nghiencuudinhluong.com/anh-huong-cua-dau-tu-truc-tiep-nuoc-ngoai-den-tang-truong-kinh-te-viet-na m-giai-doan-1990-2013/

Gui-Diby, S. L. (2016). Impact of foreign direct investments on economic growth in Africa: Evidence from three decades of panel data analyses Retrieved February 24, 2019, from https://www.sciencedirect.com/science/article/pii/S1090944314000192

Gujarati, D. N. (2003). Basic econometrics (4th ed). Boston: McGraw Hill.

Lam, N. B. (2018). Labor productivity in Vietnam and the main solution to boost labor productivity. Retrieved February 24, 2019, from http://www.gso.gov.vn/ItemPreview.aspx?ItemID=18808

Li, C., \& Tanna, S. (2018). The impact of foreign direct investment on productivity: New evidence for developing countries. Economic Modelling, 53, 83-100. https://doi.org/10.1016/j.econmod.2018.11.028

Nelson, R. R., \& Phelps, E. S. (1966). Investment in Humans, Technological Diffusion, and Economic Growth. The American Economic Review, 56(1/2), 69-75. 
Phelps, E. S. (1980). Investment in Humans, Technological Diffusion, and Economic Growth. In E. S. Phelps (Ed.), Studies in Macroeconomic Theory (pp. 133-139). Academic Press. https://doi.org/10.1016/B978-0-12-554002-5.50015-7

Ramanathan, R. (2002). Introductory Econometrics with Applications. Retrieved from http://ecsocman.hse.ru/text/19167685/

Thanh, N. T, Linh, D. T, \& Duy, N. V. (2016.). Impacts of Monetary Policy and Information Shock on Stock Market: Case Study in Vietnam. International Journal of Economics and Finance, 8(7), 132-139. https://doi.org/10.5539/ijef.v8n7p132

\section{Copyrights}

Copyright for this article is retained by the author(s), with first publication rights granted to the journal.

This is an open-access article distributed under the terms and conditions of the Creative Commons Attribution license (http://creativecommons.org/licenses/by/4.0/). 